\title{
HISTOPATHOLOGICAL FEATURES OF BREAST CANCER FROM 2005 TO 2019 IN A SINGLE CENTER IN CROATIA: AN OVERVIEW OF CHANGES FOLLOWING THE INTRODUCTION OF MAMMOGRAPHY SCREENING
}

\author{
SNJEŽANA RAMIĆ ${ }^{1}$, MELITA PERIĆ BALJA ${ }^{1}$, VESNA RAMLJAK ${ }^{1}$, SARA ZADRO ${ }^{2}$, \\ IVA KIRAC ${ }^{2}$, TOMISLAV OREŚIĆ ${ }^{3}$ and IVAN MILAS ${ }^{3}$ \\ ${ }^{1}$ Department of Oncological Pathology and Clinical Cytology, Ljudevit Jurak University Department \\ of Pathology, Sestre milosrdnice University Hospital Center, Zagreb, Croatia; \\ ${ }^{2}$ Department of Surgical Oncology, University Hospital for Tumors, Sestre milosrdnice University \\ Hospital Center, Zagreb, Croatia; \\ ${ }^{3}$ Department of Reconstructive Surgery, University Hospital for Tumors, Sestre milosrdnice University \\ Hospital Center, Zagreb, Croatia
}

\section{Summary}

INTRODUCTION: Croatia launched the National program for the early detection of breast cancer (BC) in 2006. The program targets women between the age of 50 and 69 to take a mammogram every two years. About $60 \%$ of women performed mammography through the program. The study aimed to determine the difference in breast cancer's pathohistologic features before and after the introduction of screening.

MATERIALS AND METHODS: Data was collected retrospectively in a single high volume center for women diagnosed with invasive BC in the period before the introduction of mammography screening (2005-2007; N=1833), and from newly diagnosed (2017-2019; N=2676). Statistical significance of the findings was evaluated using Chi square test.

RESULTS: We recorded a 31.5\% increase in the number of patients referred to our hospital in the post-screening period. However, no statistically significant reduction in tumor size, histological grade or the number of positive axillary lymph nodes was detected in newly diagnosed BC compared to those diagnosed over ten years ago. The mean age of BC incidence was 61 years, with the mean tumor size of $22 \mathrm{~mm}$ (median $18 \mathrm{~mm}$ ), in both periods. The significant difference occurred in the distribution of the intrinsic subtypes of $\mathrm{BC}(\mathrm{P}<.001)$. About $45 \%$ of patients were diagnosed with pT1N0 stage, in both periods.

CONCLUSION: In the post-screening period, we treated $32 \%$ more newly diagnosed breast cancers. However, pathohistological features of $\mathrm{BC}$, along with the average tumor size, did not change.

KEY WORDS: breast cancer, histopathology features, mammography screening

\section{INTRODUCTION}

Breast cancer $(\mathrm{BC})$ is the most prevalent cancer in women in Croatia, accounting for $25 \%$ of

Corresponding author: Snježana Ramić, Department of Oncological Pathology and Clinical Cytology, "Ljudevit Jurak" University Department of Pathology, Sestre milosrdnice University Hospital Center, Ilica 197, Zagreb, Croatia.

e-mail: snjezana.ramic@gmail.com cancer incidence in women, according to the Croatian Cancer Registry $(1,2)$. GLOBOCAN (3) report estimated the five-year survival in Croatia for BC patients during the 2000-2014 period to 7079\%, while EUROCARE-5 (4) reported five-year survival between $2000-2007$ as $76.3 \%(81.8 \%$ in EU) (3-8). Despite the progress in diagnostic procedures and treatment, there is still a $15 \%$ higher mortality rate of breast cancer in Croatia than in 
western EU countries $(5,6)$. Kelava et al. (9) reported an increase in the incidence of BC in Croatia 1988-2008 with an estimated annual percentage of change of $2.6 \%$, with a stable mortality rate. A presumable explanation was an increase in lifestyle-associated risk factors and improvements in diagnostics (9). Even though women over the age of 50 are at higher risk, all age groups are affected. The specialized breast units still identify breast lesions mainly through ultrasound, mammography, and physical examination (10).

Mammography screening programs for BC started in the 1980s in some EU countries and they registered a mortality reduction of up to $7 \%$ within three years of implementation (11). The Government of the Republic of Croatia launched a National Program for the Early Detection of Breast Cancer in 2006. The program encourages women between 50 and 69 years of age to take a mammogram every two years, with a $60 \%$ response rate $(1$, $5)$. Since 2006, five cycles of national mammography screening were fulfilled, with 3401 new BC cases diagnosed $(1,2)$. The latest Croatian cancer registry data for 2017 showed a reduction in BC mortality $(1,2)$.

The first aim of the program was to reduce breast cancer mortality by $15-25 \%$ and to detect $\mathrm{BC}$ in its initial stages, given that $90 \%$ of breast cancer patients are curable by proper and timely diagnosis and treatment with five-year survival going up to $96 \%$ in such cases (1). Zielonke et al. (12) reported a lack of studies from Eastern European countries, including Croatia, on mortality status due to screening. Apart from the annual reports of the Croatian National Cancer Registry, there are only a few articles in Croatia that follow the newly diagnosed BCs (9,13-17). Thus, this study aimed to look into histopathological features of breast cancer in female patients before the introduction of the screening and in newly diagnosed $\mathrm{BC}$, ten years after.

\section{PATIENTS AND METHODS}

We retrospectively analyzed data of $\mathrm{BC}$ patients diagnosed with invasive breast cancer and treated consecutively at University Hospital for Tumors (Zagreb, Croatia) during two periods: 1 ) from January 1, 2005, to December 31, 2007, and 2) from January 1, 2017, and October 31, 2019. We in- cluded all patients diagnosed with invasive breast cancer in selected periods. The first time span was chosen because it represents the earliest period for that complete data are available in electronic form for all pathology reports. In addition, these reports also contain information on HER2 status, since an immunohistochemical technique of hormone receptors and HER2 staining was already in routine practice, and the HER2 2+ cases were retested using chromogenic in situ hybridization method. We extracted the data of all patients with invasive breast carcinoma diagnosis without any specific criteria, and for some women, not all data were available (marked as unknown). The second period from 2017 to 2019 was chosen as the most recent one, and the data were extracted in the same manner.

Data on the age at the time of diagnosis and basic histopathological tumor characteristics: histological type, tumor size, histological tumor grade, pathological TNM stage, hormone receptor status of estrogen (ER) and progesterone (PR), human epidermal growth factor receptor 2 (HER2), proliferation index (Ki-67) and loco-regional spread of the tumor (positive axillary lymph nodes) was collected from pathology reports. Considering that $\mathrm{Ki}-67$, which is crucial in distinguishing Luminal A $(<20 \%)$ from Luminal B, was not analyzed during the first study period, for statistical analysis we grouped patients with hormone-positive and HER2-negative BC (e.g. Luminal type) in one category.

Apart from descriptive statistics, the groups were compared using the Chi-square test with Yeats correction by available VassarStats online calculator (http://vassarstats.net/newcs.html). The cases with unknown status were not included in the statistical analysis. Statistically significant Pvalues were defined as $<0.05$.

\section{RESULTS}

During three years, from January 1, 2005, to December 31, 2007, 1833 women with invasive breast cancer $(\mathrm{BC})$ were diagnosed and surgically treated at the University Hospital for Tumors. Almost all diagnosed patients had surgery as a curative treatment, after which they underwent adjuvant chemo/radiotherapy. Table 1 shows that over $80 \%$ of tumors were ductal invasive BC, not other- 
Table 1.

The most common histological types of invasive breast cancers in University Hospital for Tumors

\begin{tabular}{|l|l|l|}
\hline Histological type of BC & $\mathbf{2 0 0 5 - 2 0 0 7}$ & $\mathbf{2 0 1 7 - 2 0 1 9}$ \\
\hline Ductal invasive (NOS) & $1523(83.0 \%)$ & $2089(82.1 \%)$ \\
Medullar/apocrine & $35(1.9 \%)$ & $25(1.0 \%)$ \\
Micropapillary & $17(1.0 \%)$ & $27(1.0 \%)$ \\
Mucinous & $47(2.6 \%)$ & $56(2.2 \%)$ \\
Other rare types & $49(2.7 \%)$ & $44(1.7 \%)$ \\
Lobular & $162(8.8 \%)$ & $305(12.0 \%)$ \\
Unknown & - & 130 \\
\hline
\end{tabular}

wise specified (NOS). Between January 1, 2017, and October 31, 2019, 2676 patients were diagnosed with invasive BC at University Hospital for Tumors. During that period, 1748 patients had surgery as a curative treatment, after which they underwent adjuvant chemo/radiotherapy, 230 patients had metastatic or recurrent disease, while 555 patients received neoadjuvant therapy before surgery and 143 patients continued their treatment in other institutions after core needle biopsy at our hospital. The ductal invasive histological type also prevailed (Table 1 ).

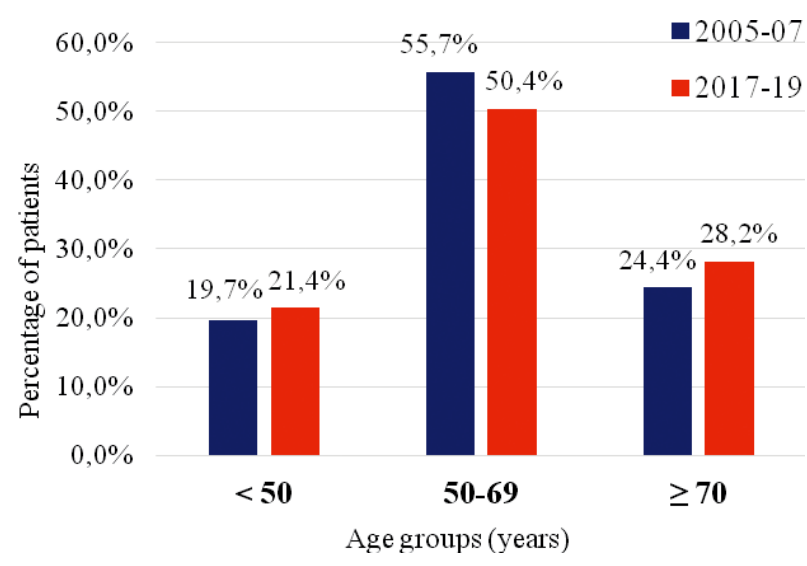

Figure 1. Distribution of the age of breast cancer patients (by age groups) at the time of diagnosis during 2005-07 and 2017-19

There was no significant difference in the average age of patients at the time of diagnosis between two periods, which was about 61 years (2293). During 2005-7, 19.7\% of breast cancer patients were younger than 50 years, and $55.7 \%$ were between 50-69 years old, while in the period 2017-19, $21.4 \%$ of patients were younger than 50 years, and

Table 2.

Comparison of histopathological features of invasive breast cancer and the age of breast cancer patients at the time of diagnosis, during the period of 2005-07 and 2017-19.

\begin{tabular}{|c|c|c|c|}
\hline Characteristics & $\begin{array}{l}2005-2007 \\
(\mathrm{~N}=1833)\end{array}$ & $\begin{array}{l}2017-2019 \\
(N=2676)\end{array}$ & $\begin{array}{l}X^{2} \\
\text { (P }- \text { values })\end{array}$ \\
\hline $\begin{array}{l}\text { Age (years) } \\
\text { Mean } \pm S D \\
\text { Median (min-max) }\end{array}$ & $\begin{array}{l}60.6 \pm 12.3 \\
61(22-93)\end{array}$ & $\begin{array}{l}61.0 \pm 13.1 \\
62(26-99)\end{array}$ & \\
\hline $\begin{array}{l}\text { Tumor size (mm) } \\
\text { Mean } \pm \text { SD } \\
\text { Median (min-max) } \\
\leq 20 \\
>20 \\
\text { Unknown }\end{array}$ & $\begin{array}{l}21.2 \pm 14.1 \\
18(3-135) \\
1108(63.2 \%) \\
645(36.8 \%) \\
80\end{array}$ & $\begin{array}{l}21.8 \pm 16.4 \\
18(1-180) \\
1455(60.3 \%) \\
957(39.7 \%) \\
264\end{array}$ & $\begin{array}{l}3.44 \\
(.064)^{*}\end{array}$ \\
\hline $\begin{array}{l}\text { Histologic grade } \\
\text { I } \\
\text { II } \\
\text { III } \\
\text { Unknown }\end{array}$ & $\begin{array}{l}220(12.2 \%) \\
1031(57.3 \%) \\
547(30.4 \%) \\
35\end{array}$ & $\begin{array}{l}292(14.4 \%) \\
1153(56.8 \%) \\
584(28.8 \%) \\
647\end{array}$ & $\begin{array}{l}4.22 \\
(.121)^{*}\end{array}$ \\
\hline $\begin{array}{l}\text { Lymph node status } \\
\text { Positive } \\
\text { Negative } \\
\text { Unknown }\end{array}$ & $\begin{array}{l}634(35.4 \%) \\
1156(64.6 \%) \\
43\end{array}$ & $\begin{array}{l}682(34.5 \%) \\
1293(65.5 \%) \\
701\end{array}$ & $\begin{array}{l}0.29 \\
(.590)^{*}\end{array}$ \\
\hline $\begin{array}{l}\text { Intrinsic type } \\
\text { Luminal } \\
\text { Lum HER2-pos } \\
\text { HER2E } \\
\text { Triple negative } \\
\text { Unknown }\end{array}$ & $\begin{array}{l}1191(65.0 \%) \\
167(9.1 \%) \\
145(7.9 \%) \\
275(15.0 \%) \\
55\end{array}$ & $\begin{array}{l}1750(67.3 \%) \\
472(18.2 \%) \\
118(4.5 \%) \\
261(10.0 \%) \\
75\end{array}$ & $\begin{array}{l}96.34 \\
(<.001)\end{array}$ \\
\hline
\end{tabular}

* $\chi^{2}$ test, unknown status was not included in analysis 


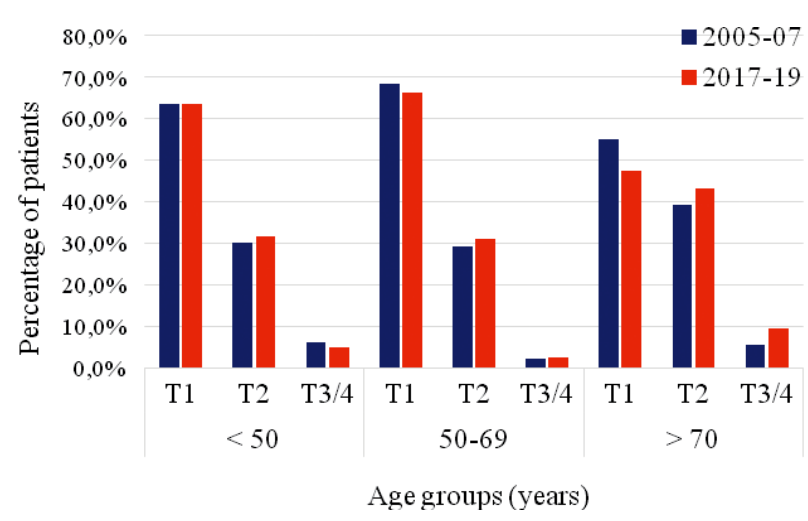

Figure 2. Distribution of $p T$ stage according to the age of breast cancer patients (by age groups) at the time of diagnosis during 2005-07 and 2017-19 (T1, tumor size $\leq 20 \mathrm{~mm}$; T2, tumor size 20-50 mm; T3/4, tumor size $>50 \mathrm{~mm}$ )

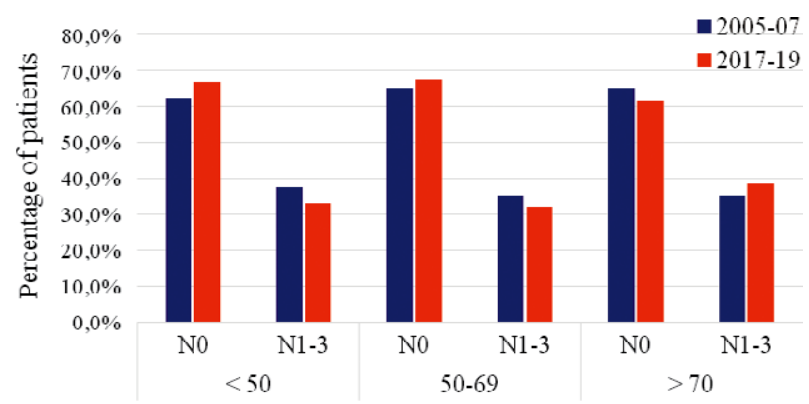

Age groups (years)

Figure 3. Distribution of $p N$ stage according to the age of breast cancer patients (by age groups) at the time of diagnosis during 2005-2007 and 2017-2019 (N0, tumors without positive lymph nodes; N1-3, tumors with one or more positive lymph nodes).

$50.4 \%$ were at the age of 50-69 years (Figure 1 ). In both periods, almost $30 \%$ of patients were $60-69$ years old, and about $2 \%$ of women were younger than 35 years. More younger patients received neoadjuvant chemotherapy in the 2017-2019 period (median 55 years), moving the primary surgical treatment to seemingly older patients (median 64 years) than in 2005-2007 (median 61).

We did not notice the difference in the median size of breast cancer $(18 \mathrm{~mm})$. More patients were diagnosed with tumors smaller than $20 \mathrm{~mm}$ during 2005-7 (63.2\% vs. $60.3 \%)$. Nevertheless, in both periods, patients younger than 50 years, on average, had $2.7 \mathrm{~mm}$ larger tumors than patients aged 50-69. No statistically significant difference was noted in the distribution of histological grade, although a small percentage of patients $(2.2 \%)$ had lower histologic grade during the 2017-19 period (Table 2).

Figures 2 and 3 depict the minor differences in pathologic $\mathrm{T}$ and $\mathrm{N}$ stages between periods. In both periods, most patients were with T1N0 stage (45\%). No significant difference was found in the percentage of patients with a negative axillary lymph node status. During both periods, about $35 \%$ of patients had positive lymph nodes $(\mathrm{P}=.590)$, but we noticed that many more newly diagnosed patients did not have axillary dissection (Table 2).

A statistically significant difference in the distribution of breast cancer intrinsic subtypes was found. Immunohistochemical expression of estrogen receptors (ER) was positive in $74.1 \%$ of patients during the $2005-7$ period, and in $85.5 \%$ of patients during the 2017-19 period. ER-positive with HER2-negative BC, belonging to the Luminal subtype, were found in $65 \%$ of patients in the period 2005-7. During 2017-19, we found the luminal subtype in $67.3 \%$ of women, of which $20.9 \%$ were Luminal A. New breast cancer cases in 201719 showed a lower percentage of triple-negative $(15.0 \%$ vs. $10 \%$ ) (Table 2). Human epidermal growth factor receptor 2 (HER2) was positive in 17 $\%$ of BC during the $2005-7$ period, while $22.7 \%$ of BC were HER2-positive during the 2017-2019 period. Initially metastatic and recurrent $B C$ in newly diagnosed patients showed a higher percentage of positive HER2 (39.3\%), while early BC showed $17.4 \%$ of HER2-positive, as in 2005-7.

\section{DISCUSSION}

Our analysis recorded a $31.5 \%$ increase in the number of patients with newly diagnosed breast cancer to our Institution. However, no difference in the age at diagnosis of $\mathrm{BC}$ patients between periods was recorded. Contrary to our expectations, we did not find any significant reduction in tumor size, histological grade, or decrease in the percentage of women with a loco-regional disease. The significant difference was in the distribution of the intrinsic subtypes of $\mathrm{BC}$, which might be due to a change in the cut-off value in the assessment of hormone receptors.

The mean age was 61 years, and about $50 \%$ of women are in the screening range of 50-69 years, while about $20 \%$ of women were younger than 50 years, in both studied periods. This distribution is 
in line with previous reports $(18,19)$. Previous data from Croatia showed a mean age of breast cancer diagnosis at 69 years with a mean size of the tumors about $25 \mathrm{~mm}(17,20)$. Our results were similar to those from the Croatian National Cancer Registry (2) who reported that $47.9 \%$ of women diagnosed with $\mathrm{BC}$ were between the ages of 50 and 69 . They also reported that $18.8 \%$ of patients were younger than 50 years including $1.7 \%$ of women diagnosed before age 35, in 2017. Žitnjak et al. also found about $2 \%$ of women younger than 35 years at diagnosis (17). Vučić et al. (13) performed research of socio-demographic risk factors for BC found that patients who underwent surgery at the University Hospital for Tumors ( $\mathrm{Za}-$ greb, Croatia) came from different Croatian Counties (mainly continental Croatia), but those who came from the Mediterranean area, were younger at diagnosis. This finding is interesting because Croatian Counties show differences in age-standardized cancer incidence rates in women, ranging from 363.8 (Bjelovarsko-Bilogorska) to 505.1 (Splitsko-Dalmatinska) (2). Erić et al. (15) found that younger patients were more likely to have positive lymph nodes than older ones. In Split region, Bezić et al. (20) detected mean size of the tumor about $25 \mathrm{~mm}$ and $41.6 \%$ with lymph nodes positive before the introduction of screening program.

Detection of BC in the early clinical stage includes smaller tumor size, positive hormone receptors, and negative axillary lymph nodes, resulting in a better prognosis and lower mortality. Contrary to our expectations, obtained results showed no significant difference in breast cancer size between periods, with an average of 21-22 $\mathrm{mm}$. In newly diagnosed patients, there were about 3\% fewer patients with tumors below 20 $\mathrm{mm}$ and the same percentage with tumors larger than $50 \mathrm{~mm}$. The number of diagnosed patients has been growing in recent years, which could be the reason for the discrepancy. Although the difference is not statistically significant, we identified $2.1 \%$ of patients with a lower histological grade in the period 2017-19. About $35 \%$ of women had loco-regional tumor spread in both periods. Admittedly, during the period 2017-2019, we observed many more patients without axillary dissection, so we assume that some of these nodes were negative at preoperative imaging or that some of these patients are still on the neoadjuvant treatment protocol, and did not receive surgery at the time of analysis. In these patients, we used core needle biopsy, and in such a small tumor sample, it is not possible to determine tumor size, histological grade, or lymph node status (21). Nevertheless, the majority of patients had stage T1N0 in both periods.

We focused on pathohistological data and did not extract data on distant metastases. The Croatian Institute of Public Health records a similar distribution. In 2012 , in $46.3 \%$ of patients, BC was localized, $38.4 \%$ of patients had positive axillary lymph nodes, and $7.1 \%$ of patients had distant metastases, while in 2017, in $38.4 \%$ of patients, BC was diagnosed in the localized stage, $24.7 \%$ patients had positive axillary lymph nodes, and $3.7 \%$ patients had distant metastases $(2,22)$.

Over the last ten years, there were several significant changes in the patohistological management of BC. In 2010, an American Society of Clinical Oncology/College of American Pathologists recommended that estrogen receptor (ER) and progesterone receptors $(\mathrm{PgR})$ are positive if there are at least $1 \%$ of tumor nuclei are positive (23). The previous cut-off was $10 \%$, which is the main reason for the higher percentage of hormone-positive tumors in recent period, and also affected the distribution of intrinsic subtypes of BC $(24,25)$. Another change in clinical practice is the determination of Ki-67 crucial for distinguishing Luminal A from Luminal B, which begun routinely in 2009; thus, we cannot estimate the percentage of Luminal A tumors in the 2005-7 period $(24,25)$. Also, our results showed an increase in HER2-positive BC in newly diagnosed patients. More HER2 analyzes performed on initially metastatic and recurrent $\mathrm{BC}$, which are more often positive, may explain the difference. HER2 testing on metastatic BC was not a routine in 2005-2007.

Our intention was not to evaluate the effectiveness of mammography screening, but to see whether the effects of screening could contribute to any improvements in the clinical status of the recently diagnosed patients. As a high volume breast cancer center (over 800 of BC cases annually) we have a high referral rate, and our data may not detect the screening benefits. Nevertheless, we treat one-third of newly diagnosed breast cancers in Croatia, so this sample might be considered representative. 


\section{CONCLUSION}

Compared to the pre-screening period, we currently treat $30 \%$ more breast cancer cases. However, our results did not show statistically significant differences in breast cancer characteristics after the introduction of mammography screening. More local/regional single-institution data publications could better illustrate both regional specificities and form a good ground for optimizing screening and treatment (step forward to cancer treatment registries).

\section{Ethics approval and patient consent for publication}

Not applicable.

\section{Competing interests}

declare.

Authors do not have competing interests to

\section{REFERENCES}

1. Croatian Institute for Public Health. [Internet]. Available from: https://www.hzjz.hr/aktualnosti/nacionalni-program-ranog-otkrivanja-raka-dojke/.

2. Croatian Institute for Public Health. Croatian National Cancer Registry. Cancer incidence in Croatia 2017. Bilten 42. Zagreb, 2020.

3. Ferlay J et al. GLOBOCAN 2012 v1.0, Cancer Incidence and Mortality Worldwide: IARC CancerBase No. 11 [Internet]. Lyon. France: International Agency for Research on Cancer, 2013. Available at: https://gco. iarc.fr/databases.php

4. De Angelis R, Sant M, Coleman MP, et al. Cancer survival in Europe 1999-2007 by country and age: results of EUROCARE 5-a population-based study. The Lancet Oncology. 2014;15(1):23-34.

5. OECD/EU. Health at a Glance: Europe 2018: State of Health in the EU Cycle. [Internet]. OECD Publishing. Paris, 2018. Available at: https://doi.org/10.1787/health _glance_eur-2018-en

6. Ferlay J, Colombet M, Soerjomataram I, et al. Cancer incidence and mortality patterns in Europe: Estimates for 40 countries and 25 major cancers in 2018. Eur J Cancer. 2018;103:356-87.

7. Allemani C, Matsuda T, Di Carlo V, et al. CONCORD Working Group. Global surveillance of trends in cancer survival 2000-14 (CONCORD-3): Analysis of individual records for 37513025 patients diagnosed with one of 18 cancers from 322 population-based registries in 71 countries. Lancet. 2018;391(10125):1023-75.

8. Šekerija M, Alfirević M, Fabijanić U, et al. Epidemiology of cancer in Croatia - recent insights and international comparisons. Libri Oncol. 2019;47(2-3):84-90.
9. Kelava I, Tomičić K, Kokić M, et al. Breast and gynecological cancers in Croatia, 1988-2008. CMJ. 2012;53 (2):100-8.

10. European Guidelines for Breast Cancer Screening and Diagnosis - the European Breast Guidelines. On Croatian. [Internet]. Available at: https://www.hzjz.hr/wpcontent/uploads/2013/11/Prijevod_eu_smjernica_rak_ dojka.pdf

11. Iwamoto Y, Kaucher S, Lorenz E, et al. Development of breast cancer mortality considering the implementation of mammography screening programs - a comparison of western European countries. BMC Public Health. 2019;19(1):823.

12. Zielonke N, Gini A, Jansen EEL, et al. Evidence for reducing cancer-specific mortality due to screening for breast cancer in Europe: A systematic review. Eur J Cancer. 2020;127:191e206.

13. Vučić K, Orešić T, Habljak K, et al. Regional differences of breast cancer risk factors in newly diagnosed female patients in Croatia. Libri Oncol. 2018;46(2-3): 47-54.

14. Puharić Z, Žulec M, Ceronja I, Šupe Parun A. High participation rate in mammography screening: experience from Croatia. Cent Eur J Public Health 2017;25 (4):303-6.

15. Erić I, Petek Erić A, Kristek J, et al. Breast cancer in young women: pathologic and immunohistochemical features. Acta Clin Croat. 2018;57(3):497-502.

16. Jurišić I, Kolovrat A, Mitrešić D, Cvitković A. National Program Breast Cancer. Coll Antropol. 2014;38(3): 961-7.

17. Žitnjak D, Soldić Ž, Kust D, et al. Demographic and clinicopathologic features of patients with primary breast cancer treated between 1997 and 2010: A single institution experience. Acta Clin Croat. 2015;54(3): 295-302.

18. American Cancer Society. Breast cancer Facts and Figures 2017-18. [Internet]. Available at: https://www. cancer.org/content/dam/cancer-org/research/cancerfacts-and-statistics/breast-cancer-facts-and-figures/ breast-cancer-facts-and-figures-2017-2018.pdf

19. Cancer Research UK. Cancer statistics. Available at: https://www.cancerresearchuk.org/health-professional/cancer-statistics/statistics-by-cancer-type/breastcancer/incidence-invasive

20. Bezić J, Tomić S, Kardum G. Minimal breast cancer in Split region of Croatia on the eve of the National Mammographic Screening Program. Breast J. 2009;15 (4):429-31.

21. Arnaout A, Lee J, Gelmon K, et al. Neoadjuvant therapy for breast cancer: updates and proceedings from the Seventh Annual Meeting of the Canadian Consortium for Locally Advanced Breast Cancer. Curr Oncol. 2018;25(5):e490-e498.

22. Croatian Institute for Public Health. Croatian National Cancer Registry. Cancer incidence in Croatia 2012. Bilten 37. Zagreb, 2014. 
23. Hammond ME, Hayes DF, Dowsett M, et al. American Society of Clinical Oncology/College of American Pathologists guideline recommendations for immunohistochemical testing of estrogen and progesterone receptors in breast cancer. Arch Pathol Lab Med. 2010; 134(6):907-22.

24. Goldhirsch A, Wood WC, Coates AS, et al. Strategies for subtypes-dealing with the diversity of breast can- cer: Highlights of the St. Gallen international expert consensus on the primary therapy of early breast cancer 2011. Ann Oncol. 2011;22(8):1736-47.

25. Nielsen TO, Parker JS, Leung $S$, et al. A comparison of PAM50 intrinsic subtyping with immunohistochemistry and clinical prognostic factors in tamoxifen-treated estrogen receptor-positive breast cancer. Clin Cancer Res. 2010;16:5222-32.

Sažetak

\title{
HISTOPATOLOŠKE KARAKTERISTIKE RAKA DOJKE OD 2005 do 2019 U JEDNOM CENTRU U HRVATSKOJ: PREGLED PROMJENA NAKON UVOĐENJA MAMMOGRAFSKOG PROBIRA
}

\author{
S. Ramić, M. Perić Balja, V. Ramljak, S. Zadro, I. Kirac, T. Orešić and I. Milas
}

UVOD: Nacionalni program za mamografski probir raka dojke u Hrvatskoj započeo je 2006, s ciljem otkrivanja raka u ranijem stadiju bolesti. Program uključuje mamografski pregled žena u dobi od 50 do 69. Cilj našeg istraživanja je utvrditi razlike u patohistološkim karakteristikama raka dojke prije uvođenja probira s novodijagnosticiranim.

MATERIJALI I METODE: Retrospektivno smo u jednom centru prikupili podatke o patohistološkim karakteristikama raka dojke bolesnica oboljelih na početku mamografskog probira (2005-2007; N=1833) i podatke o novooboljelima iz razdoblja više od deset godina nakon uvedenog probira (2017-2019; N=2676). Dobivene podatke analizirali smo upotrebom $\chi 2$ testa.

REZULTATI: Zbrinuli smo 31.5\% više novodijagnosticiranih bolesnica s karcinomom dojke. Naši rezultati nisu pokazali statistički značajne razlike u veličini tumora, histološkom gradusu ili pozitivnom status limfnih čvorova u podpazušnoj jami u skupini novodijagnosticiranih bolesnica s karcinomom dojke u usporedbi s onima iz razdoblja prije mamografskog probira. Prosječna dob oboljevanja je 61 godina s prosječnom veličinom tumora od $22 \mathrm{~mm}$ (medijan $18 \mathrm{~mm}$ ), u oba razdoblja. Oko $45 \%$ bolesnica je dijagnosticirano s pT1N0, u oba razdoblja.

ZAKLJUČAK: U razdoblju nakon uvođenja probira zbrinuli smo $32 \%$ više oboljelih od raka dojke u našoj instituciji. Nismo zabilježili razlike u patohistološkim karakteristikama tumora, niti u prosječnoj veličini tumora između ova dva perioda.

KLJUČNE RIJEČI: rak dojke, patohistološke karakteristike, mamografski probir 